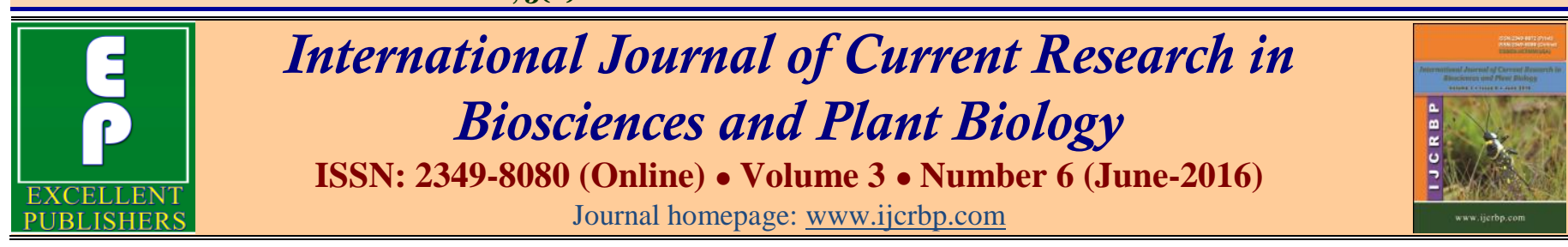

\title{
A Study on Impact of Climate Change on Children
}

\author{
Ranjan Kumar Mohanty and Sushree Shailani Suman* \\ People's Cultural Centre (PECUC), Indraprastha, Pokhariput, Bhubaneswar -751 o2o, Odisha, India \\ *Corresponding author.
}

\section{Abstract}

'Climate change' refers to a phenomenon that is experienced by the humans since its origin. It has become a serious threat to the indigenous people of the country as a whole. In addition, the climate change impacts will be getting unavoidably worse, causing massive disruption and loss to human life and other species that support our ecosystems invisibly. Climate change has a direct impact on productivity of the agricultural sector, and affects the livelihoods of the small, marginal and rain fed farmers, as well as the agricultural laborers, women, forest dwellers, and other disadvantaged and marginalized communities. Children are adversely impacted in all accounts of their life by climate change. The study tries to identify the concerns of mining and industrialization in the district of Kendujhar and suggested a list of possible measures. Odisha has always been the most vulnerable state that gets impacted by the harsh climatic changes. The state is a periodic recipient of climate risks, such as flood, cyclones and drought. The agricultural system is monsoon dependent. Health, economy and education are the other sectors that are mostly affected by the climate change. Developing understanding on the existing coping mechanisms at the community level and then propagation of this understanding at a broader are the essential remedies.
\end{abstract}

Article Info

Accepted: 26 May 2016

Available Online: 06 June 2016

\section{Ke y w o r d s}

Climate change

Children

Global temperatures

Kendujhar

\section{Introduction}

Background: Climate change necessarily brings about changes in the weather conditions on a global basis. This gives enough reason to believe that climate change could affect agricultural productivity, and cause increased health hazards. However, there has been a growing concern regarding the ill-outcomes of the change in the climate (Aggarwal and Kalra, 1994).

Problem statement: In India, particularly in Odisha, there has been a widespread and significant impact of climate change in the past 10-15 years. This has adversely affected the agricultural farmers, laborers, daily wage workers, the livelihood of the small, marginal and rain fed farmers, women, forest dwellers, and other disadvantaged and marginalized communities.
Children have been the most vulnerable target of the climate change outcomes. The range of vulnerability can be intergenerational as well as biological. World witnesses approximately one in five child deaths every year, who are less than 5 years of age. The major cause of death has been accounted by the outbreak of diseases like lower respiratory tract infections, diarrhea, and malaria, which are responsible for more than $50 \%$ of deaths. All these three diseases are believed to worsen with climate change. Global climate change is likely to increase the spread of many other infectious diseases such as food, water and vector borne diseases. In children, diseases like malaria have raised concerns with higher incidence of complications.

Hypotheses: It has been hypothesized that climate change due to deforestation and mining has put an 
immense impact on life style, culture, education, agriculture, health and over and above on the survival of the people more particularly of children in the Kendujhar district of Odisha. It has also impacted greatly on children's education and to an extent violation of their basic rights.

Objectives: The impact of climate change is inevitable and it affects human life style adversely. To understand it in details the research will find out:

- How it impacts the life of the children and to what extent it affects their upbringing.

- What are the factors leads to cultural deprivation because of climate change and environment degradation.

- How open mining impacted deforestation, environment, climate and life style of the people in Kendujhar.

The main objective of the study is to undertake an assessment study on the impact of mining and forest degradation on the rights of children to a healthy sustainable ecology and dissemination of the findings to all the stakeholders.

\section{Case of Odisha}

The state is a periodic recipient of climate risks such as flood, cyclones and draught as well. It depends on rainfall for agriculture in its non-irrigated land and struggle to save it paddy from rain in coastal areas (Aggarwal and Mall, 2002; Gadgil, 1995). Health, economy and education are the other sectors which mostly affected by the climate change or for environment degradation.

The other reason for climate change is environment degradation. The state is rich in natural resources spread over in tribal dominated districts. The state has a large quantity of mineral, forest, marine and water resource. It is the main supplier of valuable minerals such as nickel ore, coal, chromites, iron ore, bauxite and manganese. About $27 \%$ of its area is under forest cover, acting as a livelihood support for the residing population of that area (tribes). The forest area is basically superimposed with its mineral deposit, richest biodiversity regions, and water catchment of major rivers and habitat for tribal communities (Suri et al., 1996).

\section{Kendujhar - A situational analysis}

Kendujhar is a land locked district located in the northern region of Odisha, with an area of 8303 sq. km.

Anthropologically, Kendujhar has been well noticed for its very rich and varied tribal cultures. Juangas and Bhuyans are the two most primitive tribes spanning across the district, of which the Juangs claim to be the most ancient of all tribes of the world. Other tribes found in this region include the Santhal, the Oraons and the Mundas. The tribal population accounts for $44.5 \%$ of the total district population. The ver wellknown agricultural method practiced by these tribes is known as shifting cultivation, which has proved to be very harmful to their very existence. The scheduled castes account for about $11.5 \%$ of the total population.

Geographically, the district is gifted with huge mineral deposits. In addition, about one third of the total geographical area of the district is covered by dense forests. Approximately $52 \%$ of the cultivated area is considered as uplands. Baitarani, the main river of the district, caters to the need of $45 \%$ of the general use and agriculture (Aggarwal and Mall, 2002).

Agriculture is considered as the main economic activity by the people of this area, followed by mining activities (Saxena et al., 2002). Collection of minor forest produce, making of sal leaves plates or cups, have constituted the economic activities for those living in hilly terrains. Goat rearing has also emerged as one of the alternative livelihood generation program that is being financed by the Goatery Scheme under SGSY / ITDA. Tertiary activities have also gone-up in the semi-urban or rural areas (Gadgil, 1995).

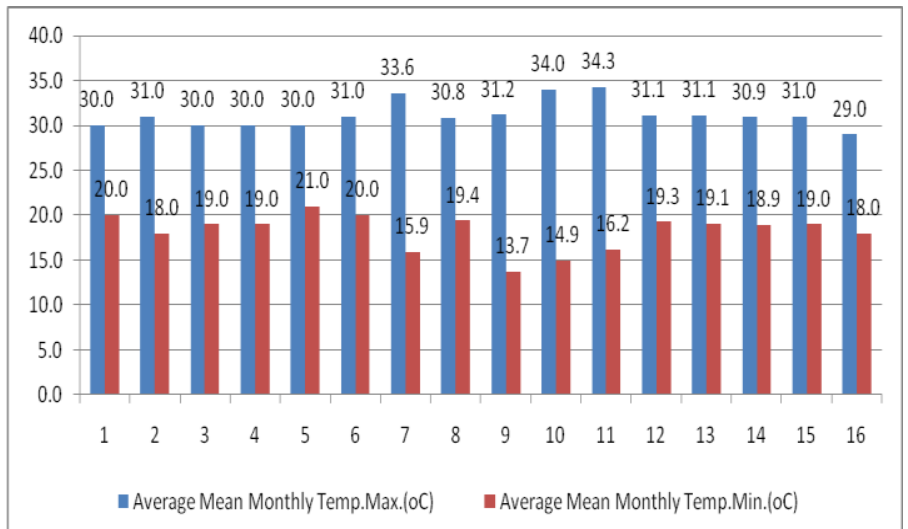

Fig. 1: Monthly average mean temperature of Kendujhar. 


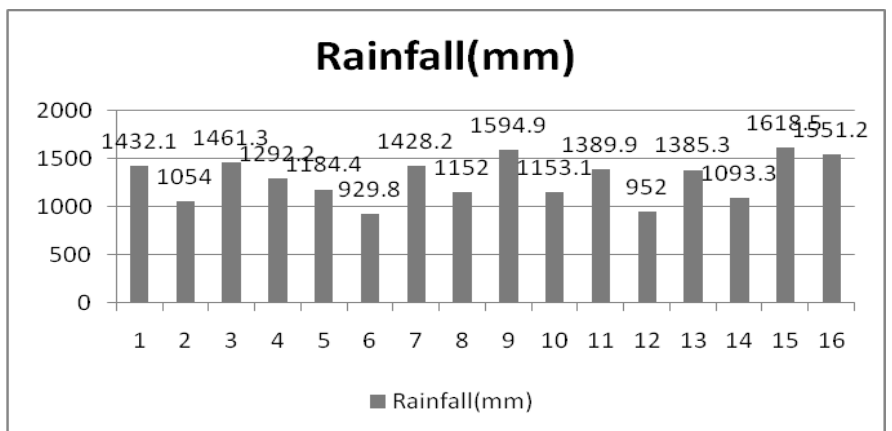

Fig. 2: Monthly average mean rainfall in Kendujhar.

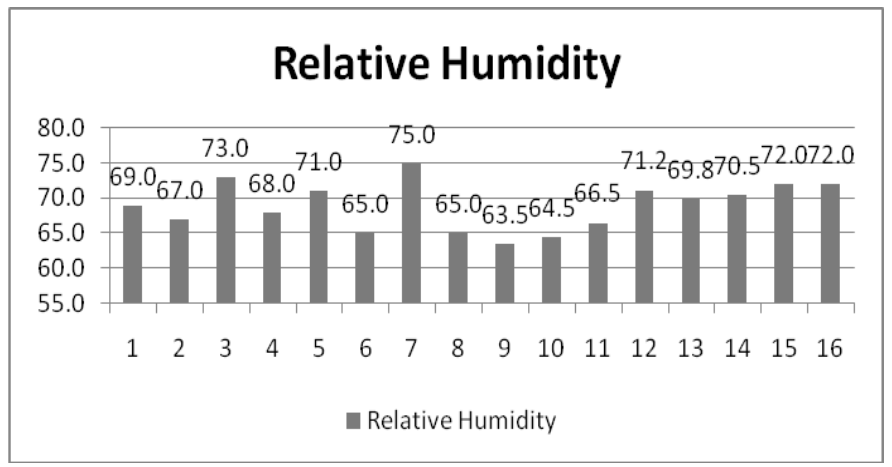

Fig. 3: Monthly average mean eelative humidity in Kendujhar.

Temperate climate prevails over the district, but few areas receive hot and dry climate during the summers. The winters are generally very cold (Figs. 1, 2 and 3). Being engulfed with hills, Kendujhar enjoys a hospitable climate throughout the year.

The climatic condition of the district is suitable for vegetable cultivation and plantation crops. The major marketable surplus food crops grown in the district consists of pulses like arhar, black gram, coarse grains like maize, crops like oilseeds, groundnut, til, mustard, rice, and vegetables like cauliflower, tomato, brinjal, sweet potato, Okra, Cowpeas, etc. are being cultivated. Horticulture crops are also grown in this region that includes mango, guava, custard apple, jackfruit, and cashew as the major plantation crop.

\section{Materials and methods}

\section{Sample}

The study was conducted by taking a sample of 10 villages of Patana block of Kendujhar district of Odisha. In depth interview was conducted from 46 people from five sample villages. These informants were from three categories, i.e., older age groups (60-70 years), middle age group (30-40 years), and child age group (10-18 years). There were six intense focus group discussions comprising of people from all sectors such as gender, age, social category, livelihood category and others. Besides this, data from secondary sources such as government data, data from various institutions (government and non-government) were studied and analyzed.

\section{Tools}

The tools were developed to collect the data from primary sources.

- Tools for interaction with informants.

- Criteria for focus group discussion.

- Criteria for collection data from secondary sources.

\section{Methodology}

Tools developed for interaction was field tested with informants before final research data collection. During the data collection, an initial interaction was held with all the informants individually and shared about the research project and its objectives. A basic understanding was developed on climate change to make the informant easy. All the interactions were in Odia and as and where/when required statements were made clear by local language with the help of PECUC team. Prior permission was obtained from the child and their parents for interaction. It was ensuring to all the informants that their name will not be reveal at any cost and we are interested to their opinion. Statement from the tools was given below for reference.

"The words 'climate change' are generally used by scientists to describe the way that the climate of the world may be changing as a consequence of human activities. Since the industrial revolution, changes in human lifestyles and technologies have increased the amounts of certain gases, such as carbon dioxide, being emitted into the atmosphere. These gases trap heat within the Earth's atmosphere producing a 'greenhouse effect' (Bhattacharya and Mitra, 1998). This causes changes to temperatures in the Earth's atmosphere. Opinion is divided: a majority of scientists believe that this alters the climate on Earth (a small minority think that human beings are not affecting the climate on Earth, as change is part of a natural process). If human beings are influencing the climate, there will be changes in temperature, rainfall, weather patterns, which will affect the natural world and human beings (Bhatia and Kaul, 1966). With this background we are trying to understand the reason for climate change and its impact. 
We choose the area because, from secondary source, it was revealed that, Kendujhar is one of the district of the state which affected by climate change. Through this study we are trying to understand how and how much it affects our life and living. Please remember that there is no right or wrong answer; I am most interested in your opinions".

The data collected from various sources are processed, computed, tabulated, analyzed and interpretation was made. Information collected from focus group discussion and secondary sources were analyzed and interpreted. The findings are substantiated with relevant data in tables and figures.

\section{Results and discussion}

Climate change is already beginning to transform life on Earth. Many researches evident that, impacts of climate change on children perhaps the greatest challenge not only for today but fears for the future as well.

Kendujhar being a land of mineral deposits, one of the most severe impacts of mining has been observed all over the district. Due to mining, many forest lands and agriculture fields or common grazing land are depleting at a faster rate (Gadgil, 1995). The compensatory afforestation has totally failed in its objective. According to an estimate by World Bank (2006), mining alone accounts for more than $2 / 3^{\text {rd }}$ of the forest land diverted. The land under agriculture in the mining areas has also shown a dip. According to State Pollution
Control Board (SCPB), there are numerous mining or industrial areas of Kendujhar that have been declared as highly polluted Zone. These places include Joda, Barbil, Koli River, etc. (Saxena et al., 2002).

Besides, forest land of district constitutes one of the major parts of forest resource of the State. Land apart, Kendujhar is home to a sizeable tribal population; including some of the most primitive tribes, those who are totally dependent on forests and agriculture for their livelihoods and survival. Rain-fed farming is the major source of livelihood for people in the area. Both land and water is the principal component of natural resource and is an indispensable requirement of the living being. Due to lack of appropriate irrigation amenities in many places, the agriculture greatly depends on the arrival of monsoon at the right time in an ample magnitude. Due to mining and deforestation it has been severely affected (Saxena et al., 2002).

Similarly, there has been rapid loss of the fauna and flora species of these affected areas, and even in the adjoining areas. The most commonly found fauna species, elephants are the worst affected.

\section{Impact of climate change on environment}

Climate change has posed serious threats to the natural environment surrounding us. Some of the glaring issues have been studied by the authors and presented in Table 1 using the Likert scale method ranging from "not important" to "very important."

Table 1. Most important environmental issues faced by the people of Kendujhar.

\begin{tabular}{llllll}
\hline \multirow{2}{*}{ Sl. No. } & \multirow{2}{*}{ Environmental issues } & \multicolumn{2}{l}{ Important } & \\
\cline { 3 - 5 } & Not & Little & Important & Very important \\
\hline 1 & Agricultural practices & 2 & 20 & 36 & 42 \\
2 & Climate change & 0 & 2 & 8 & 90 \\
3 & Destruction of tropical forests & 5 & 4 & 24 & 67 \\
4 & Genetically modified crops & 2 & 52 & 14 & 32 \\
5 & Loss of wildlife and habitats & 9 & 34 & 39 & 18 \\
6 & Pollution (air, water, land) & 12 & 22 & 13 & 53 \\
7 & Transportation issues & 32 & 25 & 22 & 21 \\
8 & Use of leftover fuel & 17 & 72 & 2 & 9 \\
9 & Use of nuclear power & 12 & 78 & 4 & 6 \\
10 & Use of pesticides & 18 & 10 & 54 & 18 \\
11 & Waste disposal & 44 & 20 & 29 & 7 \\
\hline
\end{tabular}

From the data, it has been revealed that the climate change (which means the change in weather in general term by the villagers), destruction of tropical forests, pollution of air, water are three very important environmental issues faced by the villagers. The issues which have no direct impact on the life style of the people such as, use of nuclear power, use of left over fuels, and soon have little important for environment issue. 
Due to the lack of awareness and for immediate gain, people gave little importance to genetically modified crops for environmental issue. During the discussion with older people and villagers on the issue following findings emerged:

\section{Impact of climate change on agriculture}

Climate has a primary influence on crop selection in this region. The production factors like irrigation, manuring, plant protection, precipitation, humidity, temperature, dew factor, wind and sunshine are the important weather factors that influence crop productivity starting from the land preparation till the harvest (Bhatia and Kaul, 1966; Gadgil et al., 1999; Saseendran et al., 1999). People were in the view of decreased annual rainfall all over the district in past few years. This has been substantially supported by Annual Economic Survey, stating that Odisha in last 10 years, has shown decreased productivity of the major agro products, such as paddy (by $6.8 \%$ ), pulses (by 56.4\%), oilseeds (by 44\%), potato (by 20.7), onion (by 14.4\%) and other vegetables (by $24.8 \%$ ). They said substantial losses are due to flood and drought also (Tables 2-5).

\section{Genetically modified crops}

Almost all expressed their concern over the production of paddy. They said that the country paddies (desi dhana in Odia, local language) are almost extinct. Production of new genetically modified paddies have become more by using fertilizer and pesticides. Soil is not accommodating production of country paddy due to erosion caused by climate change (Gadgil et al., 1999).

Table 2. Kind of crops cultivated in Odisha during the study period (2009-15).

\begin{tabular}{|c|c|c|c|c|c|}
\hline \multirow[b]{2}{*}{ Crops } & \multicolumn{5}{|l|}{ Production } \\
\hline & Increased & Equal & Less & $\begin{array}{l}\text { Very } \\
\text { less }\end{array}$ & $\begin{array}{l}\text { Completely } \\
\text { stopped }\end{array}$ \\
\hline $\begin{array}{l}\text { Paddy (county - desi) } \\
\text { (Arnakhuman, Angisal, Nardi, Ruskasali, Kalamkathi, Pata } \\
\text { dhana, Nilabata, Patini, Athagodia, Panisaanara, Dhinkiasiali, } \\
\text { Natakalam) }\end{array}$ & & & & & $\sqrt{ }$ \\
\hline $\begin{array}{l}\text { Paddy (imported - Sarakari) (Genetically modified crops) } \\
\text { (Puja, Lalat, Kala Champa, Arnapurna, Swarna, Sarala, Hazare } \\
\text { Chouda) }\end{array}$ & $\sqrt{ }$ & & & & \\
\hline Makka & & $\sqrt{ }$ & & & \\
\hline Mung & & & & $\sqrt{ }$ & \\
\hline Harad & & & & $\sqrt{ }$ & \\
\hline Rasi & & & & $\sqrt{ }$ & \\
\hline Mandia & & & & $\sqrt{ }$ & \\
\hline Guludi & & & & & $\sqrt{ }$ \\
\hline Khasa & & & & $\sqrt{ }$ & \\
\hline Kolatha & & & $\sqrt{ }$ & & \\
\hline Sorisa & & & $\sqrt{ }$ & & \\
\hline Biri & & & & $\sqrt{ }$ & \\
\hline
\end{tabular}

Table 3. Vegetables crops cultivated in Odisha during the study period (2009-15).

\begin{tabular}{|c|c|c|c|c|c|}
\hline \multirow{2}{*}{ Vegetables } & \multicolumn{5}{|l|}{ Production } \\
\hline & Increased & Equal & Less & Very less & Completely stopped \\
\hline Brinjal & & $\sqrt{ }$ & & & \\
\hline Tomato & & $\sqrt{ }$ & & & \\
\hline Lady finger & & & $\sqrt{ }$ & & \\
\hline Cucumber & & & $\sqrt{ }$ & & \\
\hline Potato & & & $\sqrt{ }$ & & \\
\hline Pumpkin & & & $\sqrt{ }$ & & \\
\hline Bitter guard & & $\sqrt{ }$ & & & \\
\hline Cabbage & $\sqrt{ }$ & & & & \\
\hline Cauliflower & $\sqrt{ }$ & & & & \\
\hline Beet & & $\sqrt{ }$ & & & \\
\hline Bottle guard & & & $\sqrt{ }$ & & \\
\hline Carrot & $\sqrt{ }$ & & & & \\
\hline
\end{tabular}




\begin{tabular}{lllll}
\hline Vegetables & Production & & & \\
\cline { 2 - 4 } Increased & Equal & Less & Very less & Completely stopped \\
\hline Radish & $\sqrt{ }$ & & \\
Peas & & $\sqrt{ }$ & $\sqrt{ }$ \\
Sweet potato & & & $\sqrt{ }$ \\
Beans & & & $\sqrt{ }$ \\
Lima beans & & & $\sqrt{ }$ \\
Capsicum & & $\sqrt{ }$ \\
Elephant's foot & & & \\
Ridge gourd & & & \\
Variety of Spinach & & & \\
Turnip & & & \\
Kohlrabies & $\sqrt{ }$ & & \\
Mushroom & & & \\
\hline
\end{tabular}

Table 4. Spices crops cultivated in Odisha during the study period (2009-15).

\begin{tabular}{|c|c|c|c|c|c|}
\hline \multirow{2}{*}{ Spices } & \multicolumn{5}{|l|}{ Production } \\
\hline & Increased & Equal & Less & Very less & Completely stopped \\
\hline Onion & $\sqrt{ }$ & & & & \\
\hline Garlic & & & $\sqrt{ }$ & & \\
\hline Ginger & & $\sqrt{ }$ & & & \\
\hline Chilli & & & $\sqrt{ }$ & & \\
\hline Coriander & & & $\sqrt{ }$ & & \\
\hline Mustard seed & & & $\sqrt{ }$ & & \\
\hline turmeric & & & $\sqrt{ }$ & & \\
\hline
\end{tabular}

Table 5. Fruits crops cultivated in Odisha during the study period (2009-15).

\begin{tabular}{|c|c|c|c|c|c|}
\hline \multirow{2}{*}{ Fruits } & \multicolumn{5}{|l|}{ Production } \\
\hline & Increased & Equal & Less & Very less & Completely stopped \\
\hline Mango & $\sqrt{ }$ & & & & \\
\hline Banana & & $\sqrt{ }$ & & & \\
\hline Cherrie & & & $\sqrt{ }$ & & \\
\hline Chickoo & & & $\sqrt{ }$ & & \\
\hline Pineapple & & & $\sqrt{ }$ & & \\
\hline Watermelon & & & $\sqrt{ }$ & & \\
\hline Guava & & & $\sqrt{ }$ & & \\
\hline Papaya & & $\sqrt{ }$ & & & \\
\hline Pear & & & $\sqrt{ }$ & & \\
\hline Lime & & $\sqrt{ }$ & & & \\
\hline Custard Apple & & & $\sqrt{ }$ & & \\
\hline Water Apple & & & $\sqrt{ }$ & & \\
\hline Jambun & & & $\sqrt{ }$ & & \\
\hline Litchi & & & $\sqrt{ }$ & & \\
\hline Cashew & $\sqrt{ }$ & & & & \\
\hline Jack fruit & & & $\sqrt{ }$ & & \\
\hline Coconut & & & $\sqrt{ }$ & & \\
\hline
\end{tabular}

\section{Destruction of tropical forests}

People have the view that, deforestation happens due to many reasons, such as lack of awareness, economical benefits, lack of administration, lack of love for nature, etc. Research also pointed that climate change has intensified the Asian monsoon and increased flow of river, in turn leading to increased siltation. This has further intensified the flood situation of the state (Suri et al., 1996).
Loss of wildlife and habitats (degradation of biodiversity and ecology)

People have the view that due to loss of forest and increasing population there is a huge loss in wildlife and their habitats. The world is undergoing an extinction crisis of many biological species, which is thought to have been accelerated by climate changes (Tables 6-10). 
Table 6. Wild animals (during the study period 2009-15).

\begin{tabular}{|c|c|c|c|c|}
\hline \multirow{2}{*}{ Wild } & \multicolumn{4}{|l|}{ Production } \\
\hline & Increased $\quad$ Equal & Less & Very less & Completely vanished \\
\hline Elephant & & $\sqrt{ }$ & & \\
\hline Lion & & & & $\sqrt{ }$ \\
\hline Leopard & & & $\sqrt{ }$ & \\
\hline Tiger & & & & $\sqrt{ }$ \\
\hline Deer & & & $\sqrt{ }$ & \\
\hline Bear & & $\sqrt{ }$ & & \\
\hline Boar & & & $\sqrt{ }$ & \\
\hline Snake (variety) & & $\sqrt{ }$ & & \\
\hline Fox & & $\sqrt{ }$ & & \\
\hline Wolf & & & $\sqrt{ }$ & \\
\hline Mongoose & & & $\sqrt{ }$ & \\
\hline Cheetah & & & $\sqrt{ }$ & \\
\hline
\end{tabular}

Table 7. Domestic animal (during the study period 2009-15).

\begin{tabular}{|c|c|c|c|c|c|}
\hline \multirow{2}{*}{ Domestic } & \multicolumn{5}{|l|}{ Production } \\
\hline & Increased & Equal & Less & Very less & Completely vanished \\
\hline Dog & & $\sqrt{ }$ & & & \\
\hline Cat & & & $\sqrt{ }$ & & \\
\hline Sheep & & & $\sqrt{ }$ & & \\
\hline Goat & & & $\sqrt{ }$ & & \\
\hline Donkey & & & $\sqrt{ }$ & & \\
\hline Buffalo & & & $\sqrt{ }$ & & \\
\hline Cow & & & $\sqrt{ }$ & & \\
\hline Bullock & & & $\sqrt{ }$ & & \\
\hline Squirrel & & & & $\sqrt{ }$ & \\
\hline Tortoise & & & & $\sqrt{ }$ & \\
\hline Rabbit & & & & $\sqrt{ }$ & \\
\hline Mouse & & $\sqrt{ }$ & & & \\
\hline Hen & & & $\sqrt{ }$ & & \\
\hline Frog & & & $\sqrt{ }$ & & \\
\hline Monkey & & & $\sqrt{ }$ & & \\
\hline Elephant & & & $\sqrt{ }$ & & \\
\hline
\end{tabular}

Table 8. Birds (during the study period 2009-15).

\begin{tabular}{|c|c|c|c|c|c|}
\hline \multirow{2}{*}{ Birds } & \multicolumn{5}{|c|}{ Production } \\
\hline & Increased & Equal & Less & Very less & Completely vanished \\
\hline Sparrow & & & & $\sqrt{ }$ & \\
\hline Pigeon & & & $\sqrt{ }$ & & \\
\hline Parrot & & & $\sqrt{ }$ & & \\
\hline Crow & & & & $\sqrt{ }$ & \\
\hline Duck & & & & $\sqrt{ }$ & \\
\hline Peacock & & & $\sqrt{ }$ & & \\
\hline Owl & & & & $\sqrt{ }$ & \\
\hline Vulture & & & & & $\sqrt{ }$ \\
\hline Robin & & & & & $\sqrt{ }$ \\
\hline Canary & & & & & $\sqrt{ }$ \\
\hline Kingfisher & & & $\sqrt{ }$ & & \\
\hline Swan & & & $\sqrt{ }$ & & \\
\hline Mynah & & & & $\sqrt{ }$ & \\
\hline Toucan & & & & $\sqrt{ }$ & \\
\hline Pelican & & & & $\sqrt{ }$ & \\
\hline Hornbill & & & $\sqrt{ }$ & & \\
\hline Hummingbird & & & $\sqrt{ }$ & & \\
\hline
\end{tabular}


Table 9. Insects (during the study period 2009-15).

\begin{tabular}{|c|c|c|c|c|c|}
\hline \multirow{2}{*}{ Insects } & \multicolumn{5}{|c|}{ Production } \\
\hline & Increased & Equal & Less & Very less & Completely stopped \\
\hline Cockroach & & & $\sqrt{ }$ & & \\
\hline Fly & $\sqrt{ }$ & & & & \\
\hline Dragonfly & & & $\sqrt{ }$ & & \\
\hline Mosquito & $\sqrt{ }$ & & & & \\
\hline Spider & & & $\sqrt{ }$ & & \\
\hline Bee & & $\sqrt{ }$ & & & \\
\hline Termite & $\sqrt{ }$ & & & & \\
\hline Silk moth & & $\sqrt{ }$ & & & \\
\hline Locust & & $\sqrt{ }$ & & & \\
\hline Ladybird & & & $\sqrt{ }$ & & \\
\hline Butterfly & & & $\sqrt{ }$ & & \\
\hline Bedbug & & & $\sqrt{ }$ & & \\
\hline Ant & & & $\sqrt{ }$ & & \\
\hline Red ant & & & & $\sqrt{ }$ & \\
\hline Grasshopper & & & & $\sqrt{ }$ & \\
\hline
\end{tabular}

Table 10. Forest product (during the study period (2009-15).

\begin{tabular}{|c|c|c|c|c|c|}
\hline \multirow{2}{*}{ Forest product } & \multicolumn{5}{|l|}{ Production } \\
\hline & Increased & Equal & Less & Very less & Completely vanished \\
\hline Tamarind (Imli in Hindi) & & & $\sqrt{ }$ & & \\
\hline Myrobolans & & & & $\sqrt{ }$ & \\
\hline Lac (Lakha in Odia) & & & $\sqrt{ }$ & & \\
\hline Genduli & & & & $\sqrt{ }$ & \\
\hline Nux Vomica & & & & $\sqrt{ }$ & \\
\hline Mushroom & & $\sqrt{ }$ & & & \\
\hline rowfia Ser pentine & & & $\sqrt{ }$ & & \\
\hline Simul Cotton & & & $\sqrt{ }$ & & \\
\hline Eksire fruits & & & $\sqrt{ }$ & & \\
\hline Marketing nut & & & $\sqrt{ }$ & & \\
\hline Khajuripal Patia & & & $\sqrt{ }$ & & \\
\hline Siali Leaves & & & $\sqrt{ }$ & & \\
\hline Broom stick & & & $\sqrt{ }$ & & \\
\hline Tassar Cocoons & $\sqrt{ }$ & & & & \\
\hline Forest Tulsi & & & & $\sqrt{ }$ & \\
\hline Chakunda & & & $\sqrt{ }$ & & \\
\hline Bana kulathi & & & & $\sqrt{ }$ & \\
\hline Bena-chera & & & & $\sqrt{ }$ & \\
\hline Babul seeds & & & & $\sqrt{ }$ & \\
\hline Mahua, Karanja Sikakai, Palas, and & & & $\sqrt{ }$ & & \\
\hline Sal seeds. & & & & & \\
\hline Forest Bela & & & & $\sqrt{ }$ & \\
\hline Kamal - gundi & & & & $\sqrt{ }$ & \\
\hline Baidanka & & & & & $\sqrt{ }$ \\
\hline Siali Fibres & & & & $\sqrt{ }$ & \\
\hline
\end{tabular}

\section{Causes of climate change}

From ten causes given for cause for climate change, the respondents accepted all. The degree varies from $23 \%$ to $84 \%$. Production from industry is at the highest reason for climate change shared by $84 \%$ of respondents, followed by deforestation by $79 \%$, land filling of wastes by $71 \%$, air pollution by $68 \%$ and burning of forest fuels $61 \%$; $54 \%$ of respondents responded natural variation in climate as the cause, whereas, $53 \%$ said change in use of land as the cause; $42 \%$ of respondents said increase in use of motor vehicle as the cause for climate change (Fig. 4). 


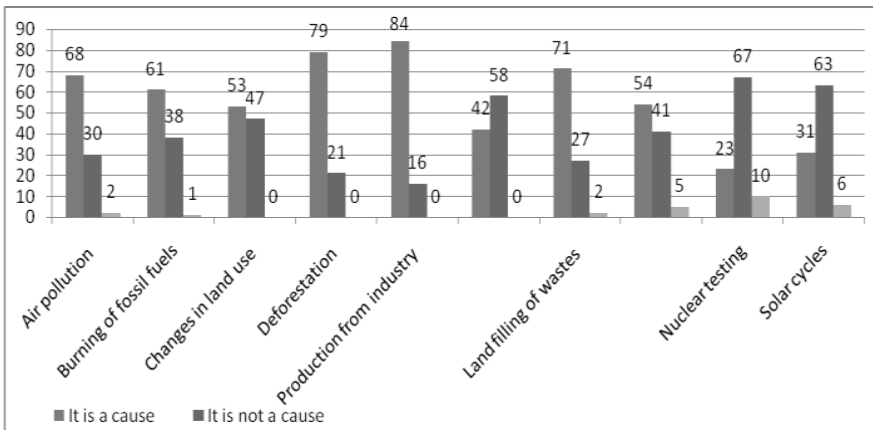

Fig. 4: Main causes of climate change.

Due to lack of awareness and information about solar cycles and nuclear testing, only informed citizens posed these two issues as the cause.

\section{Impact of mining on climate change}

Kendujhar faces a challenge in striking the precise balance between mineral resource exploitation for economic benefits and safeguarding environmental stability and social welfare. Mining impact on ecosystem of that region has been widespread (Sengupta, 2005). Therefore, the tribal dominated areas, where most of the mining roots are present, are being badly affected. Mining has surely given rise to setting up of industries locally, employing many, but it has failed to alleviate poverty through any such welfare schemes. This has also aggravated the child labor situation in the region, are they are a source of cheap labor, and usually small children are preferred by the contractors who can easily enter into the deep dug mines and extract the minerals up to the surface land. It is not possible to present an accurate picture of exact number of children employed in this sector, due to the aloofness of these mining industries and in-formalness of the mining sector (Saxena et al., 2002). The ILO estimates involvement of more than one million children worldwide in various mining activities. However, this might be an underestimation.

\section{Impact of climate change on migration}

During interviews and focus group discussion, the local climatic and environmental shifts and its impacts were observed. We observed the interlinking of environmental, social, economic, cultural, and political realms of the community. The survival patterns of these areas have changed drastically with the changing lifestyles, opting out of the younger generations from pursuing subsistence livelihood options, and economic challenges. It was clearly visible that, young generations are migrating to other city areas in search of employment. Due to lack of education and skill, many of them indulge as daily wages workers.

\section{Impact of climate change on agriculture}

From our sample villages, more than $80 \%$ of the population directly or indirectly depends on agriculture as a source of livelihood in this region.

A diverse cropping pattern has been marked in the region, over the past few decades. The villagers have shifted from the use of traditional seed varieties to hybrid ones. There has also been a rapid growth in nonfarm sector, mainly in the tertiary field (Saseendran et al., 1999).

\section{Some of major climate change impacts on agriculture have been listed below}

- Shift in the climatic zones

- Shift in the various agriculture zones

- Influence on soil texture or pattern

- Impact on the composition of soil organic matter and fertility

- Reduced soil water availability

- Pest attack, disease outbreaks and weed infestation

- Effect on plant growth

- Impact on production of crop (Saseendran et al., 1999)

\section{Impact of climate change on children}

\section{Effect on health}

Children may be a vulnerable subpopulation because of their developing physiology and anticipated long-term exposure. According to World Health Organisation (WHO, 2010), two thirds of all preventable ill health due to the environment occurs among children. In Kendujhar district, a potential association has been found between climate change and child health.

\section{Allergies}

During focus group discussion, respondents shared that due to climate change more number of children are affected by high fever, allergenic rhinitis, and allergenic asthma. Allergies are correlated to exposure to allergen 
in early stage of life of a child, which usually leads to asthma. Due to climate change there is increase in number of child allergies and asthma. Rising temperatures, changing pattern and percentage of precipitation, and climate variability is believed to alter the distribution of vector-borne diseases and greater exposure to infectious disease such as malaria, encephalitis, dengue and lyme disease.

It was shared in all most all the focus group discussion that every year around 10 to 12 children in the village are died of malaria. Malaria has accounted for maximum mortality rate in children between the age group of 3 months and 5 years, as they possess less immunity power.

\section{Impact of climate change on education}

Every child has the educational right. Yet there has been increasing incidence of drop-outs that has either emerged out due to the low quality of education provided to them or because of their economic and social backwardness. The factors aggravating such situations include gender discrimination, deepening poverty, conflict situations, child labor, child trafficking, and many others. The change in climate has further deteriorated the conditions of the children and prevented them from adopting the ability to get education.

From various focus group discussions, it was revealed that children are most vulnerable to this impact. The children face the beginning troll of disadvantages when they are brought up in an area with immense mining activities. These regions lack child care facilities, often with no schools. Hence, mothers of such children are forced to carry them to the place of work. From early childhood days, these children learn to crush stones or help with loading on trucks.

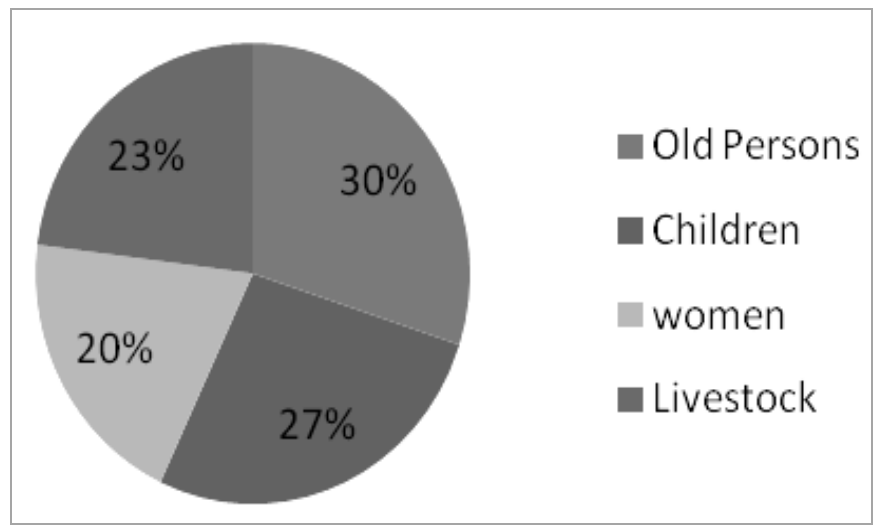

Fig. 5: Most affected by these changes.
While discussed about people who worst affected by climate, as many as $30 \%$ of informants said old people are most affected followed $27 \%$ said children, $23 \%$ said livestock and $20 \%$ said women.

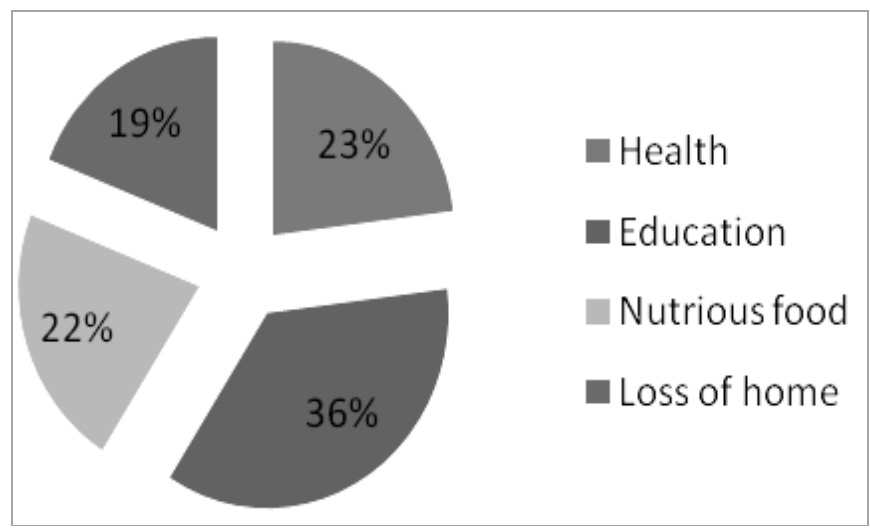

Fig. 6: Impact on children.

On discussion of impact of children, many people said education of children is most affected due to climate change followed by health, nutritious food and loss of home. The percentages of respondents were 36, 23, 22 and 19 respectively.

Drought has been considered as one of the major impacts of climate change, which results in increased food insecurity and scarcity of safe drinking water. In many of the villages, women and girls have to travel miles of kilometers to fetch water for their family. This reason is in support with maximum number of girl drop-outs from the schools. Such natural calamities have also been a cause of migration, which may be seasonal leading to increase in drop-out percentage or discontinuation in schooling for children.

Poverty is another reason for which many parents are not able to meet the minimum requirement for child education. Thus children education hampered. In this process girls are worst affected because of many reasons from socio, cultural and traditional mind set.

Changes in climate also lead to reduced agricultural productivity. In many families, due to food scarcity, children do not have their proper meals that lead to drop out from schools. Even they are not able to fully participate in the learning process. Natural disasters also cause many infrastructural damages to house, school buildings, roads etc. Immediately after disaster, many school premises are used as temporary shelters for the disaster victims leading to discontinuation of classes, and hence, setting a major drawback for the school kids. 


\section{Cultural practices related to eco-system}

Ecosystem cultural practices give rise to the cultural goods benefitting the people of that area. These environmental set-ups are generated by the constant interactions between humans and nature.

From the total respondents, $76 \%$ agreed to the fact that climate change has a direct impact on life style and ecosystem. People's engagement with environmental settings seems to be reliant, context specific and alterable. To a discussion and sharing of feeling, 64\% respondent tend to agree that changing lifestyle will help in reducing climate change, whereas $14 \%$ tend to strongly agree and $19 \%$ tend to disagree. Three percent among all respondents strongly disagreed to the effect of changing lifestyle on reducing the implications of climate change.

To the statement on how climate change impact life style, the highest percentage (76\%) of respondents added that social life was disturbed due to change in climate, $51 \%$ said population become disbursed and there is food scarcity, 28\% said that there will be lack of cooperation and cohesive living. Though less but $19 \%$ said family life are disturbed at present.

The total respondents of $89 \%$ said that the climate change adversely impacted social life and community living, $44 \%$ said there will be lack of support and cooperation and $32 \%$ said people have lost trust and trustworthiness.

\section{Conclusion}

This paper discusses a range of responses to climate change that are readily observable in Kendujhar district of Odisha and its impact on the children.

According to World Bank, Odisha emits nearly three percent of the total greenhouse gases that was reported in the year 2005. These gases are considered to be the main cause of change in climate. The mines are an important agent to climate change leading to be a cause of global warming (Bhattacharya and Mitra, 1998; Phadke and Ghai, 1994).

In the recent years, extreme weather events have highlighted the costs for Kendujhar mining, which are supposed to be unprepared towards the risk adaptation presented by the change in climate at such a faster rate (Saxena et al., 2002). Since more than a decade, Odisha has been experiencing extreme weather conditions, such as frequent floods, tropical cyclones, droughts, unusual rainfall patterns, heat waves for months, and so on. Kendujhar has been the most badly struck by such calamities. As a result, the economy of the state has been affected to a deeper extent. Floods have become an annual affair in Kendujhar district in the last three to four years. Ironically, the district has also suffered the damage from drought conditions at the same time. This has affected lives of thousands of children of Kendujhar.

The study finds that such calamities are mostly manmade. Due to industrialization and impact of modernization, the life style has changed. It has also changed the ecology and eco-system which has adversely affected the human relations and behavior with that of the environment. Environment polluted, water contaminated, air tainted, forests are deforested, human being displaced, children are badly affected from many counts such as health, education, life and living (Suri et al., 1996). The air we breathe, water we consume, the energy we harness, land we use, family in which we grow, neighborhood and community in which we move are all attributes to our environment that are polluted.

\section{Remedial measures}

- Kendujhar being the rich source of minerals, the administration of the district should implement strict environmental laws in those core areas as well as the outskirts that aim at checking all kinds of pollution.

- State must develop an updated mineral deposit map and the problems associated with it should be figured out on the map itself.

- Harnessing use of technology to address the issue relating to human development linking to mining and industry.

- National Adaptation Programmes of Action (NAPAs) must consider and take into consideration the particular climate change effects, especially on children, and their education, health and wellbeing.

- Impact of Climate Change and Environment Pollution are to be widespread more particularly for the tribes.

- School curriculum should be dealt with impact and remedies of climate change and environment pollution.

- Massive campaigns should be launched to make aware the people on Climate Change issues and Environment Pollution.

- The campaign and interventions may be planned through Schools, PRIs, NGOs, CBOs and other Voluntary Organizations to spread the key messages 
on importance of forest and water bodies in human life and preservation of our earth.

- Political parties, Policy makers, Planner to be sensitized on global warming and climate change and its impact. Hence, they must act accordingly and form and administer policy and laws (Phadke and Ghai, 1994).

- Forth estate - Media should be involved in create awareness and sharing knowledge on change on climate, pollution and its associated risks on human life.

- Government also needs to take pro-active steps in establishing a robust system for environmental monitoring in the mining areas.

- Closely work with communities in possible affected areas to develop concrete climate adaptation plans and build their capacity.

- Influencing government bodies for increased investment in developing sustainable structures, such as integrated watershed management, developing local water supplies through pipelines, as well as checking pollution in the existing sources.

\section{Conflict of interest statement}

Authors declare that they have no conflict of interest.

\section{Acknowledgement}

Our sincere thanks to terre des Hommes [Germany] -IP and AEI to support us to conduct this study. Our sincere gratitude to those children and villagers and all other respondents those who helped us by sharing their experience, thoughts, reflections and concerns. Thanks are due to those government and non-government institutions who shared their observations and information to make the study more valuable and create a learning document. Our heartfelt thanks to Sri Saswat Kumar Sahoo, Research Fellow, Indian Council for Agricultural Research (ICAR) for his valuable and critical observation, suggestion to create a document for reference; Ms. Anuradha Mohanty, Executive Director, Ms. Jyoti Mohapatra, Programme Manager, Ms. Sunanda
Biswal, NCCR of PECUC central team for their cooperation and valuable suggestion in improving the study and make its finding more educative. Thanks are due to the PECUC field team, Sri Satya Narayan Mahanta, Mr. Raju, Mr. Madan for their support and cooperation for field interaction. We would also like to thank Reseapro Scientific Services for editing assistance and assuring the quality of the manuscript.

\section{References}

Aggarwal, P.K., Kalra, N., 1994. Analyzing the limitations set by climatic factors, genotype, water and nitrogen availability on productivity of wheat. II. Climatically potential yields and optimal management strategies. Field Crops Res. 38, 93-103.

Aggarwal, P. K., Mall, R. K., 2002. Climate change and rice yields in diverse agro- environments of India. II. Effect of uncertainties in scenarios and crop models on impact assessment. Clim. Change 52, 331-343.

Bhatia, S. K., Kaul, H. N., 1966. Effect of temperature on the development and oviposition of the red cotton bug, Dysdercus koenigii and application of Pradhan's equation relating temperature to development. Ind. J. Ent. 28, 45-54.

Bhattacharya, S., Mitra, A. P., 1998. Greenhouse gas emissions in India for the base year 1990. Global Change. 11, 30-39.

Gadgil, S., 1995. Climate change and agriculture - An Indian perspective. Curr. Sci. 69, 649-659.

Gadgil, S., Abrol, Y.P., Seshagri Rao, P. R., 1999. On growth and fluctuation of Indian food grain production. Curr. Sci. 76, 548-556.

Phadke, K. G., Ghai, S., 1994. Effect of global warming on insect populations and crop damage. Shashpa. 1(2), 75-80.

Saseendran, S. A., Singh, K. K., Rathore, L. S., Singh, S. V., Sinha, S. K., 1999. Effects of climate change on rice production in the tropical humid climate of Kerala, India. Clim. Change. 12, 1-20.

Saxena, N.C., Singh, G., Gosh, R., 2002. Environmental Management in Mining Areas. Scientific Publishers, Jodhpur, India.

Suri, R.K, Kaul, O.N., Banerjee, S.P., 1996. Mining, Environment, and Forests. Society of Forest and Environmental Managers (SOFEM), Dehradun, India.

Sengupta, S., 2005. Orissa's Iron Ore Attracts Massive Investments. Steelworld, Issue no. 11, September 2005.

\section{How to cite this article:}

Mohanty, R. K., Suman, S. S., 2016. A study on impact of climate change on children. Int. J. Curr. Res. Biosci. Plant Biol. 3(6), 111-122. doi: http://dx.doi.org/10.20546/ijcrbp.2016.306.014 